\title{
Cheklist of Plants Used Traditionally to treat Menstrual Disorders in Ekiti-State, Nigeria. Need for Conservation as a Sustainable Practice in Healthcare Management in Rural Areas.
}

\author{
*Olanipekun M.K and Aladetimiro B.O \\ Department of Plant Science and Biotechnology, Ekiti State University, Ado-Ekiti, Nigeria
}

\begin{abstract}
The use of traditional plants by the people of Ekiti State, is a practice of great results to its inhabitants over generations. A checklist of plants used traditional to treat Menstrual Disorders in Ekiti South Senetorial District, Ekiti-State, Nigeria was carried out. A total of 40 plants belonging to 30 families were identified. The plant parts varied from leaves (30, 76\% plants), seeds $(5,13 \%$ plants), fruits $(3,8 \%$ plants) and stem bark (2, 3\% plants), respectively. Dysmenorrhoea (painful menstruation), Menorrhagia (excessive bleeding), Oligomenorrhoea (irregular menstruation), Hypomenorrhea (scanty menstruation) and Amenorrhea (absence of menstruation) were identified.The frequencies of citation shows that Mormodica charantia has the highest pecentage frequency of 35\%, followed by Ocimum gratissimum (27\%). The informant consensus shows that Dysmenohroea and Menorrhagia had a greater number of plants species with 0.73, while Amenohroea has the least. Most of the plants found suitably used are rare (37.5\%), abundant plant species was (32.5\%), while just abundant (30\%) respectively. The use of the plants revealed that the plants were safe (99), cheap (98), readily available (97) and the plants has little or no side effect (96). Strategies that would conserved the rare species were proposed.
\end{abstract}

Keywords: Menstrual disorders, plants, traditional management, conservation, strategies

\section{Introduction}

Recently, there are a large number of people who are affected with different type of sicknesses and diseases affecting different part of their body. Historically, the indigenous practice of managing forest and its products are not only providing man with food but also served as an agent of protection and healing to the mankind (Elujoba et al., 2005, Mahmood et al., 2013).The people, especially the women living in the rural areas or communities adopted traditional approach of indigenous tribe knowledge of medicinal plants for the treatment of various ailments and diseased conditions. Diseased conditions such as fibroids, pains, fever, breast cancer, infertilities, menstrual disorders, abortion, delivery problems, menopausal problems as challenged among others are managed through the use of plants. People in the rural area are close and having access to the plants better than people living in the urban centre (Patel, 2012; Lawal et al., 2013, Olanipekun et al., 2016). Also the suitability and the reliability of medicinal plants had been proved over the years by trial and error for many generations. Besides, plants are not scarce, they are readily available, easily exploited or harvested, they do not require special skill for their preparations.

The roles of women in a particular environment or locality are so enormous and they cannot be over emphasized. The services of women could be physically and mentally quite tasking. Women occupy various positions as leaders and subordinates in our society, homes, various government and non-governmental offices where they received wages for their susteinance. Women are role models in the communities, they are mostly consulted using homemade remedies and traditional health management of their household members as primary health services. They are very strong and occupy leadership positions, so valuable as a major stakeholder in the agro-forestry activities, economic, education, health and political settings etc. However, in spite of all these qualities and responsibilities, women have a naturally endowed health challenged condition called Menstruation (Patel, 2012; Lawal et al., 2013; Zahra and Adeel, 2014; Olanipekun et al., 2016).

Menstruation is a monthly process of shedding the old or matured uterine lining of the uterus to make way for the new ones. Menstruation is a quite challenging experience that normally occurs at every average interval of 28 days in women. Every woman is expected to experience an average of 400 menstrual cycles in her child bearing lifetime (Ayodele, 1988; Yadav et al., 2006). Millions of women across the globe, both in rural and urban communities suffer from menstrual pains syndromes such as menorrhagia (excessive bleeding), dysmenorrhoea (painful menstruation), oligomenorrhoea (irregular menstruation), hypomenorrhea (scanty menstruation) and amenorrhea (absence of menstruation). The most common symptoms ranges from abdominal pains, mood instability, irritability, nervous tension, headache, increased appetite, palpitations, weaknesses, dizziness and fainting, weight gain, swollen hands and feet, swelling and sensitivity of breast, penchant to sweets, swelling and abdominal bloating, depression, poor memory and insomnia (Rajni et al., 2009; Singh et 
al.,1999; Singh, 2006; Olanipekun et al., 2016). These challenge has been handled through convectional methods as well as traditional ways by the rural people. Modern medical facilities are available with the help of government intervention and the services have been helping in managing cases associated with the menstruation through the primary health care services both in the rural and urban centers. However, there are cases of potential side effects such as severe pains, nausea, vomiting, skin rashes, digestive problems which in most times put the users off from adopting conventional methods. Also, the services are expensive compared to their economy and the drugs sometimes are not readily available, therefore making the rural people still involving in the use of traditional knowledge they have gathered over years in curing many diseases. The use of herbal medicines are found to be the saving grace because plants are cheap, easily available and patient friendly. Hence, most rural dwellers rely on their indigenous traditional knowledge of herbal medicine to cure different ailments, rather than the use of modern medicine.

The importance of medicinal plants in meeting the treatment of menstrual disorders cannot be overemphasized. The use of Plants from generation to generation has proved effective because plants contain a lot of bioactive ingredients that are responsible for its action. However, the various anthropogenic activities in world is resulting in the reduction in the availability of forest products, thus making the forest facing the threat of depletion (Elujoba et al., 2005,Ayodele 2005, Saeed et al., 2004, Tagola and Diallo, 2005, Olanipekun et al., 2013). Also there is a gross dearth in the documentation and conservation of plants having the potential to treat menstrual disorder in the study area.

Keeping this in view, the present study was initiated with the aim of documenting the traditional plants treating menstrual disorders with the view of identifying the rare ones and propose the conservation measures that ensures their availability for its continuous existence.

\section{Materials and Methods}

\section{The Study Area}

The research was conducted in five villages in Ekiti West Local Government Area of Ekiti-State, namely Ipole-Iloro Ekiti, Ikogosi Ekiti, Erijiyan Ekiti, Aramoko Ekiti and Erio Ekiti. Ekiti West has an area of $346 \mathrm{~km}$ and a population of 165,277 (Population Census, 2006).

Ethno- botanical information on medicinal plants found to be useful in the treatment of menstrual disorders were obtained through the administration of Semi-Structured questionnaires distributed to the respondents which were mostly women, farmers, traditional clinic workers, traditional healers, herbalists and individuals who have the knowledge about the use of plants around them or have inherited the knowledge from their forefathers.

\section{Methods}

The identified plants were collected and documented. The voucher specimens of the identified plants were prepared and deposited at the herbarium unit of Plant Science and Biotechnology Department of Ekiti State University, Ado Ekiti. The scientific name, family name, parts used, abundance status, methods of preparation and mode of administration were documented. Similarly, the frequency of citation and informants concensus agreement which revealed the reliability and credibility on the utilization reports were also obtained. Also, the conservation measures that ensured the availability and sustainability of the rare species were identified.

The data were spread on Excel sheet and encoded using Statistical Package for Socio Sciences (SPSS). Descripive statistical tools (percentages, frequencies and mean) were used to sumarize the data.

Frequency of citation $(\%)\left(\mathrm{F}_{\mathrm{c}}\right)$ was calculated by using the following formula:

$\left(F_{c}\right)=$ Number of informants who cited the species $X 100$

Total number of informats interviewed

Factors of informant concensus $\left(\mathrm{F}_{\mathrm{IC}}\right)$ on the knowledge used for different menstrual disorder was calculated using the methods provided by (Trotter and Logan,1991) and (Heinrich et al.,2009)

$\mathrm{F}_{\mathrm{ic}}=\underline{\mathrm{N}}_{\underline{\mathrm{uR}}}-\mathrm{N}_{\mathrm{TAXA}}$

$\mathrm{N}_{\mathrm{uR}}-1$

$F_{\text {ic }}=$ Factor of informant consensus

$\mathrm{N}_{\mathrm{uR}}=$ Number of used reports in a particular ailment

$\mathrm{N}_{\text {TAXA }}=$ Number of taxa used to treat that particular ailment

\section{Results and discussion}

A total of 40 botanicals belonging to 30 families were identified (Table 1). The common names and the various used parts were documented.The predominant parts that are used were leaves (30, $76 \%$ plants), seeds $(5,13 \%$ plants), fruits (3, $8 \%$ plants) and stem bark (2, $3 \%$ plants), respectively (Fig. 1$)$. The habit of the plants were mostly trees $(18,46 \%)$, shrubs $(10,27 \%$,), climber $(4,8 \%)$ and herbs $(8,19 \%)$, respectively (Fig. 2). 
Also, the frequency of citation was found that Mormodica charantia has the highest pecentage frequencyof 35 $\%$, followed by Ocimum gratissimum (27\%) (Table 1). Table 2 shows the informant consensus on the traditionally used species for treat various menstrual disorders. It was observed that dysmenohroea and menorrhagia were conditions that had a greater number of plants species with the informant consensus of 0.73 , while Amenohroea has the least (Table 2). Also, most of the plants found suitably used are rare $(37.5 \%)$ on the abundance scale compared to the plants that are very abundant $(32.5 \%)$ and just abundant (30 \%), respectively (Table 3). The respondents perception on the use of the plants revealed that the plants were safe (99), cheap (98), readily available (97) and the plants have little or no side effect (96), respectively (Table 4).

Table 1. Plants used in treating menstrual disorders in Ekiti State.

\begin{tabular}{|c|c|c|c|c|c|c|}
\hline No & Botanical name & Family & Common name & Part used & $\begin{array}{l}\text { Habit/Life } \\
\text { form }\end{array}$ & $\mathbf{F}_{\mathrm{c}}(\%)$ \\
\hline 1 & Abrus precatorius L. & Papilioniaceae & Crab's eye & Leaf & Climber & 1 \\
\hline 2 & Aframomum melegueta k. Schum. & Zingiberaceae & Alligator pepper & Seed & Herb & 3 \\
\hline 3 & Ageratum conyzoides $\mathrm{L}$. & Asteraceae & Goat weed & Leaf & Herb & 5 \\
\hline 4 & Alchornea laxiflora $\mathrm{L}$. & Euphorbiaceae & Canestiks & Leaf & Shrub & 10 \\
\hline 5 & Allium ascalonicum $\mathrm{L}$. & Liliaceae & Onions & $\begin{array}{l}\text { Leaf/ } \\
\text { bud }\end{array}$ & Herb & 3 \\
\hline 6 & Aspilia africana C.D Adams & Asteraceae & $\begin{array}{l}\text { Haemorrhage plant, } \\
\text { Bush marigold }\end{array}$ & Leaf & Herb & 10 \\
\hline 7 & Baphia nitida Lodd. & Leguminoceae & Cam wood & $\begin{array}{l}\text { Stem/ } \\
\text { Leaf }\end{array}$ & Tree & 1 \\
\hline 8 & Bryophyllum pinnatum Lam. & Crassulaceae & $\begin{array}{l}\text { Resurrection or life } \\
\text { plant }\end{array}$ & Leaf & Herb & 1 \\
\hline 9 & Chromolaena odorata Linn. & Asteraceae & Bitter bush & Leaf & Shrub & 1 \\
\hline 10 & Cynometra mannii Oliv & Fabaceae & Cynometra & Bark & Tree & 1 \\
\hline 11 & Citrus aurantifolia Christm & Rutaceae & Auce lime & Fruit & Tree & 2 \\
\hline 12 & Cissampelos owariensis P. Beau & Menispermaceae & $\begin{array}{l}\text { Cissampelos } \\
\text { pregnancy herb }\end{array}$ & Leaf & Shrub & 19 \\
\hline 13 & Cola nitida Schot & Sterculiaceae & Cola & Seed & Tree & 2 \\
\hline 14 & $\begin{array}{l}\text { Detarium microcarpum Guill\& } \\
\text { Perr. }\end{array}$ & Caesalpinaceae & Detarium & Leaf & Shrub & 5 \\
\hline 15 & $\begin{array}{l}\text { Diospyrous alboflavescens } \\
\text { Gurke. }\end{array}$ & Ebenaceae & Diospyrous & Bark & Tree & 4 \\
\hline 16 & Ficus exasperata Vatil. & Moraceae & Sand paper leaves & Leaf & Tree & 5 \\
\hline 17 & Heliotropium indicum $\mathrm{L}$ & Boraginaceae & Indian helotrope & Leaf & Herb & 3 \\
\hline 18 & Hyperium perforatum John watt. & Hypericaceae & Hypefora & Leaf & Tree & 1 \\
\hline 19 & Ipomoea batatas Lam. & Convolvulaceae & Sweet potatoe & Leaf & Climber & 1 \\
\hline 20 & Jatropha curcas Leeuwen. & Euphorbiaceae & $\begin{array}{l}\text { Barbados nut / } \\
\text { purging nut }\end{array}$ & Leaf & Tree & 10 \\
\hline 21 & Jatropha gossypifolia L. & Euphorbiaceae & Cotton leaf & Leaf & Shrub & 21 \\
\hline 22 & Jaundea pinnate Lawsonia. & Connasaceae & Lawsonia & Leaf & Shrub & 1 \\
\hline 23 & Khaya ivorensis Lovoa. & Mohaceae & Mahogamy & Bark & Tree & 2 \\
\hline 24 & Kigelia africana Lam. & Bignoniaceae & Africa sausage tree & Fruit & Tree & 9 \\
\hline 25 & Momordica charantia L. & Cucurbitaceae & Bitter gourd & Leaf & Climber & 35 \\
\hline 26 & Mucuna flagellipes $\mathrm{H}$. & Fabaceae & Ijokun & Leaf & Climber & 1 \\
\hline 27 & Musa sapientum L. & Musaceae & Banana & Fruit & Tree & 2 \\
\hline 28 & Myrianthus arboreus P. Beauv. & Moraceae & Myrianthus & Leaf & Tree & 2 \\
\hline 29 & Newbouldia laevis P. Beauv. & Bignoniaceae & Africatulip tree & Leaf & Tree & 1 \\
\hline 30 & Ocimum gratissimum $\mathrm{L}$. & Lamiaceae & Mint & Leaf & Herb & 27 \\
\hline 31 & Parquetina nigrescens Afzel. & Periplocaceae & Atufa & Leaf & Climber & 22 \\
\hline 32 & Pennisetum purpureum Seifu. & Poaceae & Elephant grass & Leaf & Herb & 2 \\
\hline 33 & $\begin{array}{l}\text { Phyllanthus muellerianus. } \\
\text { Kuntze }\end{array}$ & Phyllanthaceae & $\begin{array}{l}\text { Leaf flower / stone } \\
\text { breaker }\end{array}$ & Leaf & Herb & 3 \\
\hline 34 & $\begin{array}{l}\text { Piper guineense Schum. \& } \\
\text { Thonn }\end{array}$ & Piperaceae & $\begin{array}{ll}\begin{array}{l}\text { Africa } \\
\text { pepper }\end{array} & \text { Black } \\
\end{array}$ & Seed & Climber & 2 \\
\hline 35 & Pizralima nitida. & Apocynaceae & Pizra plant & Seed & Shrub & 2 \\
\hline 36 & $\begin{array}{l}\text { Senna podocarpa (Guill. \& } \\
\text { Pers.) }\end{array}$ & Caesalpinaceae & Senna & Leaf & Tree & 1 \\
\hline 37 & Spondias mombin L. & Anarcadaceae & Yellow mombin & Leaf & Tree & 2 \\
\hline 38 & Talinum triangulae Rbda. & Portulacacicea & Water leaf & Leaf & Herb & 2 \\
\hline 39 & Tragia spathulata Lam. & Euphorbiaceae & $\begin{array}{l}\text { Indian stinging / } \\
\text { climbing nettle }\end{array}$ & Leaf & Herb & 12 \\
\hline 40 & Vernonia amygdalina L. & Asteraceae & Bitter leaf & Leaf & Tree & 6 \\
\hline
\end{tabular}

$\mathrm{F}_{\mathrm{c}=}$ Frequency of citation

Plant parts used for treating menstrual disorders 


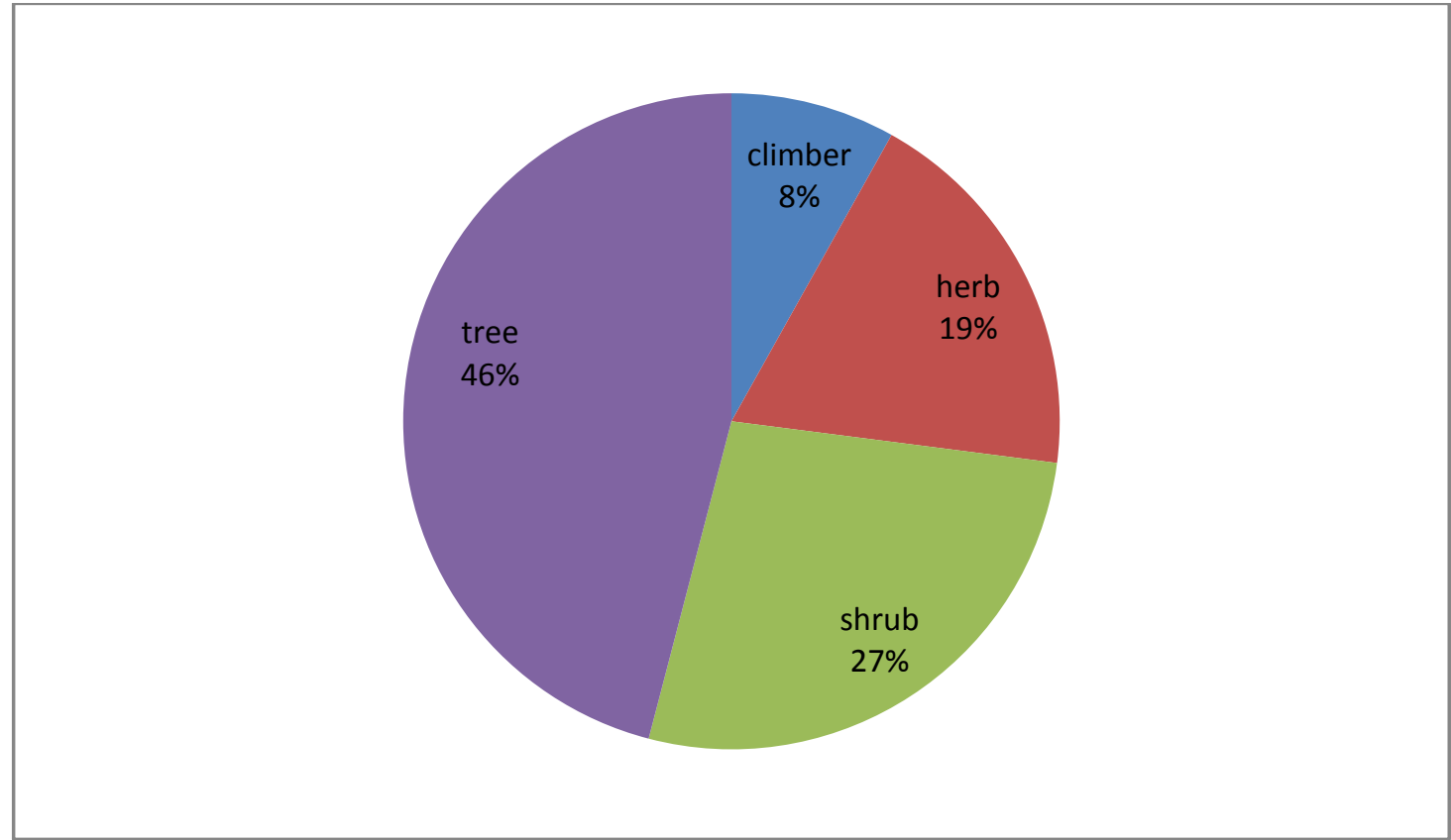

Figure 2: Growth habits of the identified plants.

Table 2: Informant consensus on the use of plant for the treatment of menstrual disorders in Ekiti-State

\begin{tabular}{|c|c|c|}
\hline Menstrual disorder, & Species extracted and used for cure & $\mathbf{F}_{\text {ic }}$ \\
\hline Dysmenorrhoea & $\begin{array}{l}\text { Ocimum gratissmum, Vernonia amgdalina, Khaya } \\
\text { ivorensis, Aspilia africana, Momordica charantia, } \\
\text { Detariu microcapum, Cissampelos owarensis Senna } \\
\text { podocarpa, Jatropha curcas, Jatroph gossypifolia } \\
\text { Alchornea laxiflora, Parquetina nigrescenes, Hypericum } \\
\text { perforatum, Abrus precatorius, Spondia mombin, Heliotricum } \\
\text { indicum, Citrus aurantifolia, Pizralima nitida, Tragia spathulata, } \\
\text { Chromolaena odorata, Ipomoea batatas, Myrianthus arboreus, } \\
\text { Newbouldias laevis, Aframomum melegueta and Cola nitida }\end{array}$ & 0.73 \\
\hline Oligomenorrhoea & $\begin{array}{l}\text { Pennisetum purpureum, Cissampelos owariensis, } \\
\text { Momordica charantia, Aspilia africana, Alchornea } \\
\text { laxiflora, Parquetina nigrescenes, Helitrocum indium, } \\
\text { Hyperium perforatum, Abrus precatorius, Bryophyllum } \\
\text { pinnatum, Detarium microcarpum, Ficus exasperate, } \\
\text { Jatropha curcas, and Jaundea pinnate }\end{array}$ & 0.54 \\
\hline Menorrhagia & $\begin{array}{l}\text { Ficus exasperata, Aspila africana and Spondia mombins, } \\
\text { Alchornea laxiflora, Ocimum gratissimum, Momordica } \\
\text { charantia, Alchornea laxiflora Hypericum perforatum, } \\
\text { Parquetina nigrescenes, phyllathus muelerianas, } \\
\text { Cissampelos owariensis, Jatropha curcas } \\
\text { Jatropha gossypifolia, Heliotricum indicum } \\
\text { and Ageratum conyzoides. }\end{array}$ & 0.73 \\
\hline Hypomenorrhoea & $\begin{array}{l}\text { Mucuna flagellipes, Jatropha gossypifolia, } \\
\text { Ageratum conyzoides, Jatropha curcas }\end{array}$ & 0.52 \\
\hline Amenorrhoea & $\begin{array}{l}\text { Momordica charantia, Alchornea laxiflora, } \\
\text { Hyperium perforatum, Ficus exasperate, Phyllanthus } \\
\text { muelerianas, Ocimum gratissimum, Parquetina nigrescenes, } \\
\text { Cissampelos owariences, Jatropha curcas, and Jatropha gossypifolia . }\end{array}$ & 0.17 \\
\hline
\end{tabular}


Table 3: The availability of the identified plants species used in treating menstrual disorder in Ekiti-State.

\begin{tabular}{|c|c|c|}
\hline Abundance & Species & $\begin{array}{l}\text { Proportion (\%) } \\
\text { of the species }\end{array}$ \\
\hline
\end{tabular}

Very abundant

Ageratum conyzoides, Alchornea laxiflora,

Allium ascalonicum, Aspilia Africana, Chromolaena

odorata, Citrus aurantifolia, Momordica charanta,

Musa spp, Ocimum gratissimum, Piper guinenses,

Spondias mombin, Talinum triangulae, Vernonia amygdalina

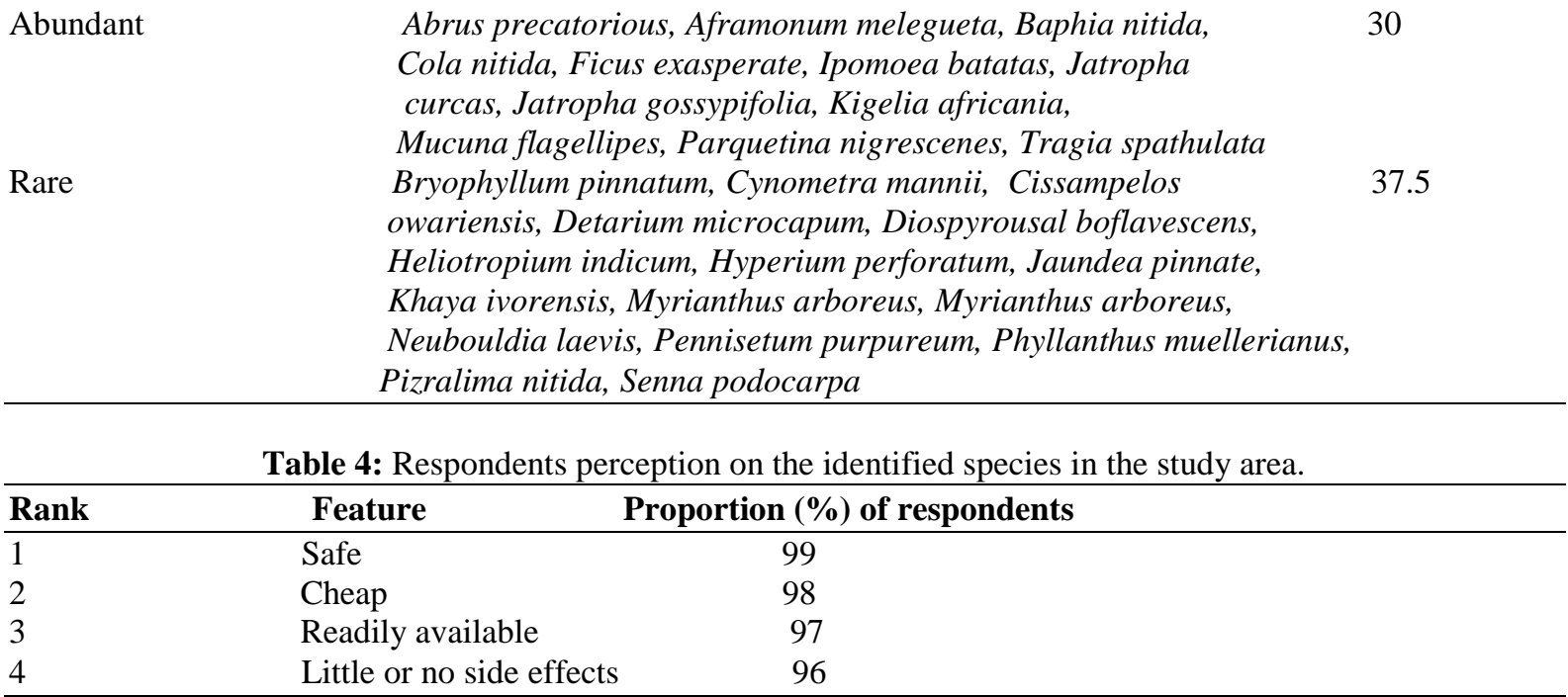

\section{Discussion}

The results revealed the study area was consisted of various plants suitable as medicinal remedies against diseases. Various part of plants such as leaves, fruits, seeds and stem barks are used traditionally in the preparation and administration of herbal medicine for the treatment and prevention of painful conditions associated with menstrual disorders. However, leaves are the most used part out of stem bark and roots. Leaves are believed to be readily available with high potential of bioactive ingredients which are capable of effecting the healing processes. Also, leaves have regenerative capacity and its extraction does not always destroy the exisitence of the plants unlike the use of stem bark and the roots which are annihilative and destructive when harvested Kayode, 2005; Kayode, 2007). The most frequently and popularly used plant is Momordica charantia (35\%) and Ocimum gratisimum $(27 \%)$. This could be attributed to the availability of the plants in the study area. Momordica charantia (35\%) and Ocimum gratisimum are abundant in large scale; the forest vegetation in the study area support its growth. The use of plants for herbal remedies is common in the study area as the respondents agreed that plants are in abundance, proved over times, easily prepared in various forms, cheaper and culturally acceptable. Momordica charantia locally known as Ejinrin leaves are prepared by decoction to extract the active ingredients to treat the menstrual disorders and other associated diseases in the study area. Mucuna flagellipes locally known as Ijokun, the extract is allowed to be fermented after extraction for few days. This ensures adequate extraction and increase the concentration of the active ingredients against Hypomenorrhoea.. The use of plants prepared locally has been of helped in managing the pains associated with sicknesses over generations. This is probably because plants are available, effective, holistic in nature and they are non resistance to most microorganisms caused diseased conditions. The use of plant parts for the treatment of ailments may be due to the presence of bioactive ingredients present in the plants. Some of the medicinal plants reported in this study have been previously reported by (Lambo, 1997; Mendonca and Menezes, 2003; Ibe and Nwafor, 2005; Mahmood et al., 2013; Arowosegbe et al., 2015) who asserted the biological activites and the bioactive constituents responsible for their therapeutic properties which justifies and validates the efficacies of the plants.The study area is a forest zone where natural resources are much and the annual rainfall is adequate. There are evidences that quite a number of these species are common because the vegetation supports their growth. However the collections are usually done indiscriminately and unscientifically without any consideration for size and age, thus resulting in species depletion.

A considerable proportion of the identified botanicals were obtained from the natural environment ( home gardens and the forest area). To gain credibility, scientific study utilizes traditional knowledge must be 
reliable. In ethnobotanical studies, concensus analysis provides a measure of reliability for any given claim proving reliable evidence. High value of $\mathrm{F}_{\mathrm{IC}}$ indicates the agreement of selection of taxa between the informants, whereas a low value indicates disagreement (Mendonca and Menezes, 2003; Kayode et al., 2015). Some of the plants were found very abundant $32.5 \%$ in the study area, however, there is about $30 \%$ that is just abundant while $37.5 \%$ is rare or sparsely available. The rate at which forest and natural environment in the study area are exploited and destroyed is alarming, thus making the availabilty of plants threatened, therefore a need to conserve forest for future use. Also, the unsustainable collection of generative and vegetative parts of medicinal plants from natural resources are annihilative and predatory, thereby reduced the populations as well as decreased multiplication and regenerating power of plants. Therefore, the need to embark on in-situ and ex-situ conservation measures, conservation strategies such as domestications of rare species, embarking on afforestation programmes, public enlightenment on the effect of deforestation and genetic erosion of species in their natural habitat among others should be advocated for.

\section{Conclusion}

The use of plants is very important in treating ailments in the study area. However, the exploitation of plants have not been intensively monitored, thus led to the reduction in their availability to the end users. There is therefore an urgent need to create awareness among the inhabitants about its sustainable collection. Conservation measures such as, domestication, public enlightenment, small scale for home or personal use as well as large scale for trade of medicinal plants should be encouraged.

\section{References}

[1]. Arowosegbe S, Olanipekun MK and Kayode J (2015) Ethnobotanical survey of medicinal plants used for the treatment of Diabetes mellitus in Ekiti-State Senatorial District, Nigeria. J. of Botany, Plant science and Phytology Vol. 2(4), 1-8

[2]. Aumeerudy Y (1994) Local Representations and management of agro forest on the periphery of kerinciseblat national park Sumatra, Indonesia. People and Plants working paper, UNESCO, Paris.

[3]. Ayodele BJ (2005) The Medicinal importance of leafy vegetable of South West Conservation in Nigeria. Conservation of Medicinal Important Leafy vegetables in Nigeria. Department of Botany and Microbiology, University of Ibadan.

[4]. Elujoba, AA, Odaleye OM and Ogunyemi CM (2005) Traditional medicinal development for medical and dental primary health care delivery system in Africa. Africa Journal of Traditional complementary and Alternative Medicine. Vol. 3 Pp46.

[5]. Heinrich M, Moerman, ES and Leonti M (2009) Ethnopharmacological field studies; A critical assessment of their conceptual basis and methods. J ethnopharmacological,124;1-17.

[6]. Kayode, J. (2004) Conservation perception of endangered tree species by rural dwellers of Ekiti-State Nigeria. J. of sustainable forestry. 19 (4):1-9

[7]. Kayode J. (2007) Conservation implication of timber supply pattern in Ekiti-State Nigeria. Research J. of forestry 1 (2): 86-90.

[8]. Kayode J, Omotoyinbo MA, Ayeni MJ and Oyedeji AA (2015) Stembark and Root extractivism in Ekiti-State Nigeria: Need for conservation as a sustainable innovation in Healthcare Management in Rural Areas. American J. of Bioscience 3(2):28-33

[9]. Kayode J and Akinluyi SM (2016) Documentation and Conservation of wild edible plants in Ado-Ekiti Region Ekiti-State, Nigeria. Canadian J. of Agricultural and Crops. Vol. 1 (2) 43-49.

[10]. Lambo W (1997) The healing powers of herbs with special 34 references to obstetrics. African Medicinal Plants. University of Ibadan Press.

[11]. Lawal I, Amao A, Lawal K, Alamu, T, Sowunmi IL(2013) Phytotherapy approach for the treatment of gynaecological disorder among women in Ido Local Government Area of Ibadan, Oyo State, Nigeria. J. Adv. Sci. Res. 4, 41-44.

[12]. Mahmood A, Rashid S, Malik RN (2013a) Determination of toxic heavy metals in indigenous medicinal plants used in Rawalpindi and Islamabad cities, Pakistan. J. Ethnopharmacol.148, 158-164.

[13]. Mahmood A, Mahmood A, Malik RN, Shinwari ZK (2013b) Indigenous Knowledge of medicinal plants from Gujranwala district, Pakistan. J.Ethnopharmacol.,148,714-723.

[14]. Mendonca Filho R.F.W, Menezes FS (2003). Estudo da utilizacao de plant as medicinal is pela populacao da Ilha Grande, RJ. Rev. Bras. Farmacogn.13,55-58.

[15]. Martin GJ, Barrow S, Cunningham AB and Shanley P (2001) Source for appalling ethnobotany to conservation and community development; managing resources. People and plants handbook, Issue 6, May, 2001.

[16]. Olanipekun MK, Kayode J and Akomolafe DS (2013) Ethno-botanical importance and phytochemical analysis of some medicinal plants commonly used as herbal remedy plants in Oye Local Govt Area of Ekiti State Nigeria. IOSR Journal of Agriculture and Veterinary Science Pp28-31.

[17]. Olanipekun MK, Arowosegbe S, Kayode, J and Oluwole TR (2016) Ethnobotanical survey of medicinal plants used in the treatment of women related diseases in

[18]. Akoko Region of Ondo-State, Nigeria. J. of medicinal Plant research Kenya Vol 10 (20) Pp 270-277

[19]. Patel PK, 2012. Ethnogynaecological uses of plants from Gujarat, India. Bangla. J. Plant Taxon. 19, 93-94.

[20]. Rajini D, Kumar A and Kour M (2009) Knowledge and practices related to menstruation among tribal (Gujjar) adolescent girls, Ethno-med, (3) 43-48

[21]. Saeed M, Arshad M and Ahmed A (2004). Ethnophytotherapies for the treatment of various diseases by the local people of Pakistan. Pp101

[22]. Shiwari MI and Khan MA (2000) Folk use of medicinal herbs of Magalla Hills National Park, Islam badad. J. of Ethnopharmacological (69), 45-56

[23]. Singh AJ (2006) Place of menstruation in the reproduction lives of women of rural North India. Indigenous Journal Commu. Med, (31) $10-14$

[24]. Singh V and Pandey RP (1996) Ethnomedicinal plants used for veneral and gynaecological diseases in Rajasthan, J. Eco Taxo Bot Addr. Series (12), 154-165

[25]. Singh MM, Devi R and Gupta SS (1999) Awareness and health seeking behavior of rural adolescent school girls on menstrual and reproductive health problems. Ind. J. Med. Sci. (53) 439-443 
[26]. Sofowora A (1982) The State of Medicinal Plant Research in Nigeria. Nigeria Society of Pharmacology, University of Ife P.404.

[27]. Tagola and Diallo (2005) Ethno pharmacological survey of different uses of medicinal plants from Mali.(West Africa) in the region of Doila. Journal of Ethno Biology. Pp. 1-7

[28]. Trotter R and Logan M (1991). Informant consensus; a new approach for identifying potentially effective medicinal and diet: biobehavioural approaches. Edited by Etkin N.L. Bedfort hills, New York: Redgrave Publishers;1986: 91- 112.

[29]. Yadav JP, Kumai J and Siwach P (2006) Folk medicine used in gynecology and other related problems by rural population of Haryana. Indian Journal of Traditional Knowledge, (5) 323-326

[30]. Zahra S and Adeel M (2014) Ethno-gynaecological knowledge of medicinal plants used by Baluchj tribes, Southeast of Baluchistan, Iran. Brazilian Journal of Pharmacognosy 706-715 